\title{
The effect of low ancient greenhouse climate temperature gradients on the ocean's overturning circulation
}

\author{
Willem P. Sijp and Matthew H. England \\ ARC Centre of Excellence for Climate System Science, University of New South Wales, Sydney, NSW 2052, Australia \\ Correspondence to: Willem P. Sijp (w.sijp@unsw.edu.au)
}

Received: 10 September 2015 - Published in Clim. Past Discuss.: 9 October 2015

Accepted: 9 February 2016 - Published: 29 February 2016

\begin{abstract}
We examine whether the reduced meridional temperature gradients of past greenhouse climates might have reduced oceanic overturning, leading to a more quiescent subsurface ocean. A substantial reduction of the pole-toEquator temperature difference is achieved in a coupled climate model via an altered radiative balance in the atmosphere. Contrary to expectations, we find that the meridional overturning circulation and deep ocean kinetic energy remain relatively unaffected. Reducing the wind strength also has remarkably little effect on the overturning. Instead, overturning strength depends on deep ocean density gradients, which remain relatively unaffected by the surface changes, despite an overall decrease in ocean density. Ocean poleward heat transport is significantly reduced only in the Northern Hemisphere, as now the circulation operates across a reduced temperature gradient, suggesting a sensitivity of Northern Hemisphere heat transport in greenhouse climates to the overturning circulation. These results indicate that climate models of the greenhouse climate during the Cretaceous and early Paleogene may yield a reasonable overturning circulation, despite failing to fully reproduce the extremely reduced temperature gradients of those time periods.
\end{abstract}

\section{Introduction}

The polar warmth of the greenhouse climates in the Earth's past represents a fundamentally different climate state to that of today, with a strongly reduced temperature difference between the Equator and the poles (e.g. Greenwood and Wing, 1995). Rose and Ferreira (2013) show that oceanic poleward heat transport reduces the meridional temperature gradient by causing an enhanced greenhouse effect in extrat- ropical latitudes. The ocean's meridional overturning circulation (MOC) redistributes heat across the globe, constituting a prime driver for oceanic poleward heat transport. The goal of this study is to examine the MOC in a past greenhouse climate characterised by weaker meridional temperature gradients, with mainly palaeoclimate but also future climate perspectives.

Greenhouse conditions prevailed during the Cretaceous (146-66 Ma), with significantly warmer temperatures than present (Huber et al., 2001), especially at high latitudes (Barron, 1983). Littler et al. (2011) find that the earliest Cretaceous climate was stable and warm, with a significantly lower meridional temperature gradient than today. Global warmth increased during Cenomanian (94-101 Ma) to Turonian (90-94 Ma) times and reaching its maximum during the Late Turonian (Clarke and Jenkyns, 1999; Wilson et al., 2002). Oxygen isotope data point to high tropical temperatures of $33-34^{\circ} \mathrm{C}$ (Norris et al., 2002; Schouten et al., 2003; Wilson et al., 2002) and southern subpolar Atlantic Ocean temperatures of $30-32^{\circ} \mathrm{C}$ (Bice et al., 2003), suggesting extreme polar warmth. Deep and bottom ocean temperatures exceeded $10^{\circ} \mathrm{C}$ (Brass et al., 1982) at this time, indicating high polar winter temperatures for this period as deepwater formation takes place during winter.

Greenhouse conditions extend beyond the Mesozoic, persisting over many millions of years and ending with the initiation of the Antarctic ice cap at the Eocene/Oligocene transition (EOT, $33 \mathrm{Ma}$ ) (e.g. Zachos et al., 2001a). The early Eocene (56-48 Ma) saw particularly reduced meridional temperature gradients (Barron, 1987; Wolfe, 1995; Greenwood and Wing, 1995). High-latitude winter warmth is reflected also in Eocene deep ocean temperatures, thought to have been around $10^{\circ} \mathrm{C}$ higher than today (Miller et al., 
1987; Lear et al., 2000; Zachos et al., 2001a). The low meridional temperature gradients of the past greenhouse climates pose a significant problem to our general understanding of how the climate works, as climate models fail to simulate past polar amplification of the greenhouse effect, and the responsible climate feedbacks remain unclear (Valdes, 2011).

The phenomenon of polar amplification of global climatic change is present in model projections of future climate (e.g. Holland and Bitz, 2003). One immediately obvious mechanism is the surface albedo feedback, where warming leads to snow and ice melt and thus greater solar energy absorption. However, global climate model (GCM) studies (Alexeev, 2003, 2005) also find feedbacks involving increased longwave forcing and latent heat transport (Langen and Alexeev, 2007; Caballero and Langen, 2005) important in amplifying polar climate change in the present-day. During the past greenhouse climates, feedbacks related to the cryosphere were absent, and these atmospheric factors must be even more important in causing polar warmth.

One promising recent line of research into explaining past polar and winter warmth comes from Abbot and Tziperman (2008), who propose that the Eocene high latitudes were kept warm by deep atmospheric convection. Unlike today, in the absence of the insulating sea-ice, more moisture and heat could enter the atmosphere. They proposed this destabilised the winter air column, initiating atmospheric convection and creating deep optically thick convective clouds, in sharp contrast to today's stratified subpolar atmosphere. At high latitude, such cloud cover would have a net warming effect, creating a positive feedback on surface ocean temperature. This mechanism is most pronounced in winter, suggesting a clue to the mild winters of greenhouse climates.

Rose and Ferreira (2013) propose a mechanism whereby enhanced low-latitude ocean heat transport can warm the mid- to high latitudes, without cooling the Tropics (see also Enderton and Marshall, 2009; Herweijer et al., 2005). Here, extratropical ocean warming arising from enhanced heat transport triggers a convective adjustment of the troposphere. Enhanced greenhouse trapping associated with convective moistening of the upper troposphere in the midlatitude storm tracks leads to warming that extends to the poles by atmospheric processes. The enhanced ocean heat transport causing these effects could for instance arise from the altered geography at the time of the greenhouse climates (e.g. via a tropical circumpolar ocean; Hotinski and Toggweiler, 2003).

The very low meridional temperature gradients of the past greenhouse climates pose a significant challenge to numerical climate models (Roberts et al., 2009; Huber and Caballero, 2003; Valdes, 2011; Sijp et al., 2014), particularly for the early Eocene. The modelling challenge here is that increased greenhouse gases may yield balmy simulated polar regions, but they also overheat the Tropics. Huber and Caballero (2011), finding extratropical cloud-related effects in their Eocene simulation, suggest a possible end to the low-gradient problem, provided that very high $\mathrm{CO}_{2}$ concen- trations (4400 ppm) are prescribed. Lunt et al. (2012) find reasonable agreement between models and sea surface temperature (SST) data for the Eocene at high $\mathrm{CO}_{2}$ (2500$6500 \mathrm{ppm}$ ), with the important exception of the Southwest Pacific and the Arctic. Abbot et al. (2009) show that the convective cloud feedback proposed by Abbot and Tziperman (2008) is active in an atmospheric GCM in modern configuration with an atmospheric $\mathrm{CO}_{2}$ concentration of $2240 \mathrm{ppm}$ and in a coupled GCM in Eocene configuration at $560 \mathrm{ppm}$.

In broad agreement with the work of Rose and Ferreira (2013) and Abbot and Tziperman (2008), recent advances in modelling the low-gradient greenhouse climates involve an enhanced greenhouse effect in the extratropical regions. Indeed, radiative feedbacks play an important role in amplifying the temperature effects of opening the Drake Passage in the model study of Yang et al. (2013). This indicates that, while theories involving such feedbacks may vary in detail, their broad predictions about the atmosphere's radiative balance should be given serious consideration as a possible explanation of past greenhouse warmth. This motivates research on the effects of the extremely low temperature gradients ensuing from enhanced high-latitude greenhouse warmth on the world ocean, which is the central focus of this paper.

Classical geostrophic scaling (Robinson and Stommel, 1959; Robinson, 1960) suggests a linear relationship between the meridional density gradient and the ocean's meridional overturning strength. Furthermore, a relationship of this kind is also maintained in subsequent friction-based scaling arguments (Gnanadesikan, 1999; Schewe and Levermann, 2010) and formulas (Sijp et al., 2011a), and has been found in ocean models (e.g. Rahmstorf, 1996).

There are two proposed driving mechanisms of the present Atlantic Meridional Overturning Circulation (Kuhlbrodt et al., 2007), involving a balance between deep sinking and low-latitude diapycnal upwelling driven by downward turbulent diffusion of heat, or wind-driven upwelling in the Southern Ocean associated with the absence of a Drake Passage gap (Toggweiler and Samuels, 1995). The choice of numerical model parameters could influence the relative importance of each mechanism, and potentially the overturning response to temperature gradients. However, Schewe and Levermann (2010) show that meridional density differences set the overturning strength in both scenarios. Density gradients remain relatively constant in our experiments, suggesting robustness of our results. The absence of a deep Drake Passage gap in our experiments suggests the importance of diapycnal upwelling as a deep water removal mechanism.

At higher temperatures, temperature is the dominant factor in setting density gradients. A reduced meridional temperature gradient could therefore be expected to yield a reduced density gradient, and therefore, based on the scaling arguments in the literature cited above, the more "sluggish" ocean overturning that is sometimes informally invoked for the past greenhouse climates. Here, by reduced overturning 
we mean an overall average reduction over longer timescales in a relatively steady climate and in the absence of sharp perturbations on decadal to centennial timescales.

The possible effect of low temperature gradients on the ocean's overturning strength is therefore important to study. Furthermore, modelling low-gradient greenhouse climates allows insight into how the overturning might behave in future climate scenarios. In this paper we simulate a Cretaceous climate under an enhanced extratropical greenhouse effect in an Earth system model. We choose a Cretaceous model geography as it represents a period deep within the greenhouse climate timeframe, yet similar to the Eocene geography in that the continents are recognisable and both characterised by closed or narrow Southern Ocean gateways. As such, our results are not confined to the Turonian, but serve to illustrate a wider timeframe of greenhouse climates. We find that the meridional overturning circulation remains surprisingly robust with respect to these changes in climatic ocean forcing, including a reduction of the oceanic wind stress.

\section{Model and experimental design}

We use a modified version of the intermediate complexity coupled model described in detail in Weaver et al. (2001), the so-called UVic model. This model allows suits a processbased approach, allowing simulations over thousands of model years. Furthermore, by controlling the atmospheric responses, it allows us to tease out the oceanic response to an altered atmospheric radiative balance associated with an enhanced extratropical greenhouse effect.

The model consists of an ocean general circulation model (GFDL MOM Version 2.2 Pacanowski, 1995) coupled to a simplified one-layer energy-moisture balance model for the atmosphere and a dynamic-thermodynamic sea-ice model based on that of Albert (1976). Air-sea heat and freshwater fluxes evolve freely in the model, while a non-interactive wind field is employed. The turbulent kinetic energy scheme of Blanke and Delecluse (1993) based on Gaspar et al. (1990) represents vertical mixing due to wind and vertical velocity shear, as well as buoyancy. More information about the technical modifications to the model can be found in Sijp et al. (2011b). The model is the Cretaceous UVic model used in Sijp et al. (2014), where geography represents a time slice around $90 \mathrm{Ma}$ of the Cretaceous Turonian period (90$94 \mathrm{Ma}$ ), as shown in Fig. 1. Wind stress is taken from a GENESIS model simulation described in Floegel et al. (2005), with identical continental configuration and elevated $\mathrm{CO}_{2}$. The present model differs from that in Sijp et al. (2014) in terms of the cloud albedo. This prescribed field is described below, and has been made symmetrical around the Equator to remove the present-day bias that exists in the standard UVic model, and has been smoothed.

The standard simulation, named CNTRL, is similar to the Cretaceous UVic model described in Sijp et al. (2014). To

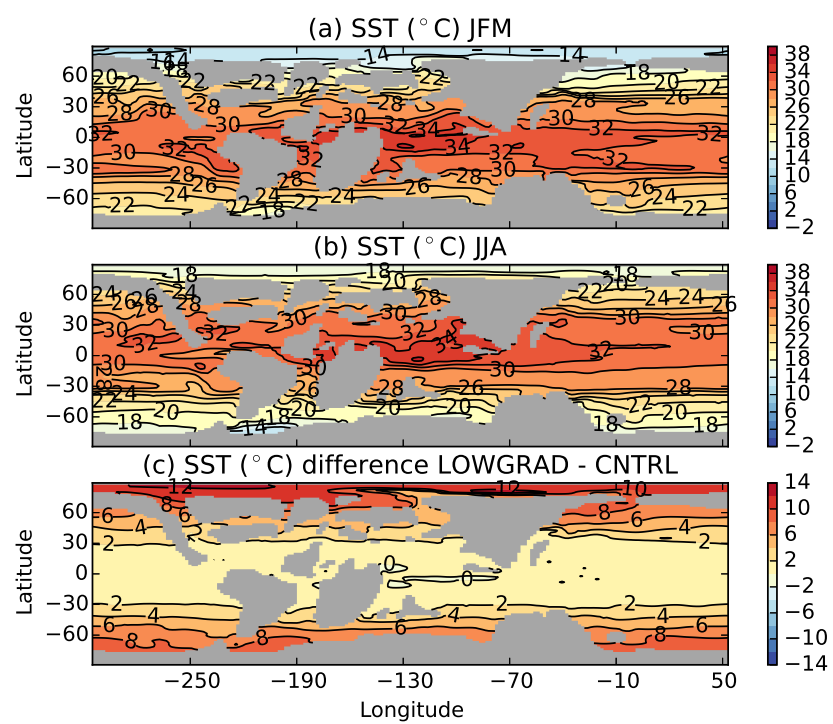

Figure 1. Average sea surface temperature $\left(\mathrm{SST},{ }^{\circ} \mathrm{C}\right)$ for the simulation with altered radiative balance, LOWGRAD, in (a) January, February, March, (b) June, July, August and (c) SST difference LOWGRAD - CNTRL. Model geography is that of the Turonian period (90-94 Ma) of the Cretaceous.

examine the effect of a strongly reduced meridional temperature gradient arising from a polar enhancement of the greenhouse effect, we have run a modified version of the control case to equilibrium, LOWGRAD, where the outgoing longwave radiation has been scaled so as to yield an enhanced meridional profile, as shown in Fig. 4b. This effectively models an enhanced greenhouse effect at high latitudes, where outgoing longwave radiation from the top of the atmosphere is reduced, thus appearing colder from space. Vice versa, the increased outgoing longwave radiation at low latitudes implies a reduced greenhouse effect there. This is to achieve a low meridional temperature gradient, to examine its effect on the global ocean. The third simulation, LOWGRADWIND, is identical to LOWGRAD, but with oceanic wind stress reduced by a factor of half. Atmospheric albedo is constant across the experiments. Table 1 lists the three simulations. All simulations have been run in excess of 6000 model years to reach a stable climate equilibrium.

\section{Results}

Figure 1 shows boreal winter (Fig. 1a) and summer (Fig. 1b) SSTs in our modified simulation LOWGRAD. Arctic ocean temperatures remain above $12^{\circ} \mathrm{C}$ in winter and above $16^{\circ} \mathrm{C}$ in summer. Summer SST of the order of $20-24^{\circ} \mathrm{C}$ are attained at the Antarctic margin, with a localised drop to $18^{\circ} \mathrm{C}$ in the proto-Weddell Sea. Winter temperatures are generally around $16-18{ }^{\circ} \mathrm{C}$, and lowest temperatures are attained near the Antarctic margin in the proto-Weddell sea, just east of the southern tip of South America. Here, winter tempera- 
Table 1. Description of numerical equilibrium simulations.

\begin{tabular}{ll}
\hline Name & Explanation \\
\hline CNTRL & The control simulation \\
LOWGRAD & Enhanced polar greenhouse effect, as shown in Fig. 4a \\
LOWGRADWIND & As LOWGRAD, but with ocean wind stress reduced by half \\
\hline
\end{tabular}

tures drop to close to $14{ }^{\circ} \mathrm{C}$. In contrast, we will see that deep ocean temperatures are around $17^{\circ} \mathrm{C}$, and therefore deep sinking must take place elsewhere. Indeed, analysis of ocean convection shows that the deep sinking site is located at the Antarctic margin in the Pacific sector of the Southern Ocean (Fig. 2). The deep ocean temperature is consistent with the winter surface temperature of this region (Fig. 1b).

The MOC in the CNTRL simulation is very similar to that discussed in Sijp et al. (2014), with a strong deep global overturning cell originating at the Antarctic surface of $39.0 \mathrm{~Sv}$ (Sverdrup, one Sv is $10^{6} \mathrm{~m}^{3} \mathrm{~s}^{-1}$ ) and weak shallow overturning in the Northern Hemisphere of $10.1 \mathrm{~Sv}$, as shown in Fig. 3a. This overturning remains remarkably similar in LOWGRAD (Fig. 3b), with a small increase in southern sinking strength of $43.0 \mathrm{~Sv}$, and a reduction in the shallow northern cell, despite the significant reduction in meridional density gradient (Fig. 4f). Again, the southern sinking cell in LOWGRADWIND is stronger than in CNTRL, $41.7 \mathrm{~Sv}$, although now the northern cell is eliminated (Fig. 3c). This suggests that the shallow northern overturning cell in $\mathrm{CN}$ TRL is driven by both the wind and meridional density gradients.

Figure $4 \mathrm{~d}$ shows that the meridional SST gradient is significantly reduced in the model upon the enhancement of the greenhouse effect at high latitudes in LOWGRAD compared to the control case. Annually averaged SST of around $20^{\circ} \mathrm{C}$ is now attained around Antarctica, and the coldest annually and zonally averaged Arctic temperatures are around $15^{\circ} \mathrm{C}$. Tropical SST remains around $32-33^{\circ} \mathrm{C}$, due to the prescribed increase in outgoing longwave radiation there, in accordance with our aim of achieving a lower temperature gradient and not overheating the Tropics. The reduced wind stress simulation LOWGRADWIND yields a very similar temperature profile to LOWGRAD. In contrast to SST, sea surface salinity (SSS) remains very similar for CNTRL and LOWGRAD, whereas reducing the winds in LOWGRADWIND yields overall fresher values, particularly in the Northern Hemisphere (Fig. 4e). As can be expected from the reduced SST gradient and the relatively unchanged SSS gradients, sea surface density is significantly reduced in LOWGRAD, and LOWGRADWIND, compared to CNTRL. With SSS gradients relatively unchanged, this is due to the reduced SST gradient in the LOWGRAD and LOWGRADWIND experiments.

The reduced meridional temperature gradient in LOWGRAD leads to a significant reduction in oceanic poleward (a) Convection depth $(\mathrm{km}) \mathrm{CNTRL}$

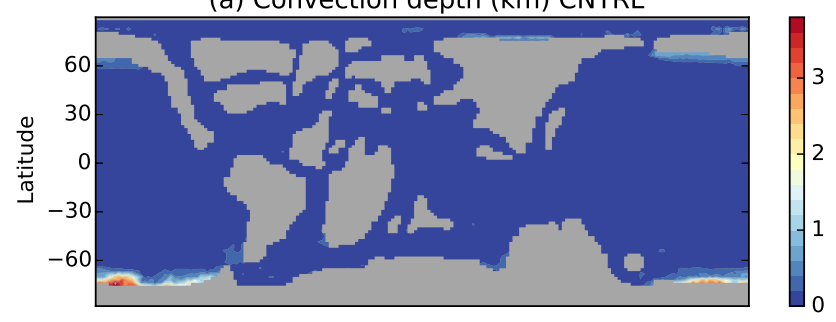

(b) Convection depth (km) LOWGRAD

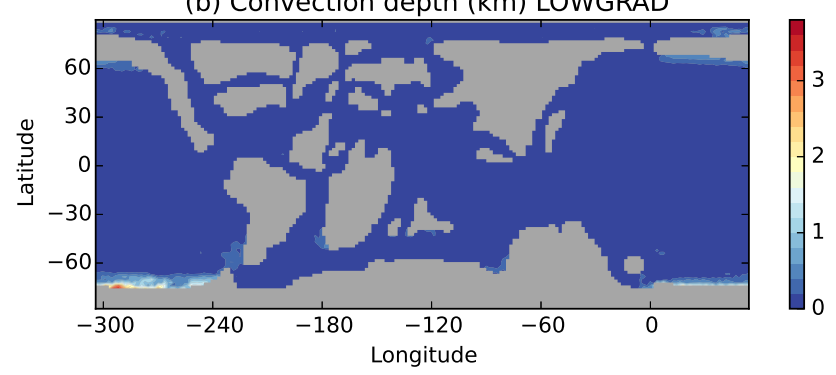

Figure 2. Maximum convection depth in $\mathrm{km}$ in (a) CNTRL and (b) LOWGRAD.

heat transport (PHT, Fig. 4c) compared to CNTRL in both hemispheres. This is to be expected, as now the gyre circulation and the overturning circulation work across a lower temperature gradient. This is because the heat transport should be proportional to the gyre strength and the temperature difference between the cool and warm branches of these circulation patterns. Reduction in wind stress in LOWGRADWIND leads to a further significant reduction in oceanic poleward heat transport (compared to LOWGRAD) only in the Northern Hemisphere, where values now become very small compared to the Southern Hemisphere. This is because here the gyre strength is significantly reduced, further reducing heat transport. Furthermore, the collapse of the weak shallow Northern Hemisphere overturning cell that is driven by density gradients and winds (as discussed above, Fig. 3) also contributes to reduced heat transport. The Southern Hemisphere is significantly less sensitive to the effects of reducing the meridional temperature gradient and the wind stress because heat transport there is dominated by the large Southern Hemisphere sinking cell, and this cell is insensitive to the changes in wind and temperature. This suggests that poleward heat transport in past greenhouse climates was dominated by the ocean's overturning circulation. 
(a) CNTRL (39.0 Sv)

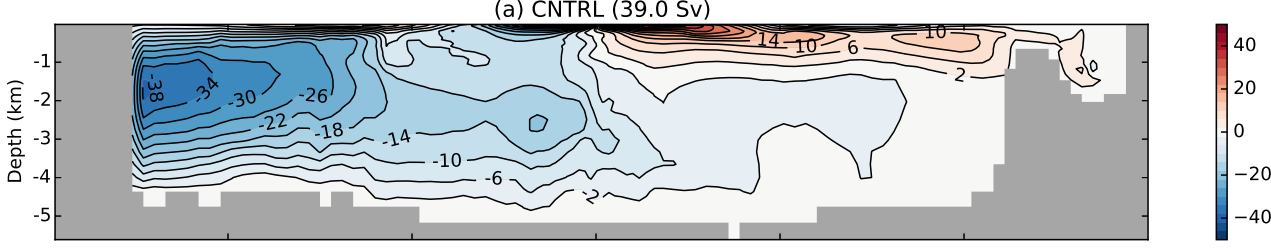

(b) LOWGRAD (43.0 Sv)

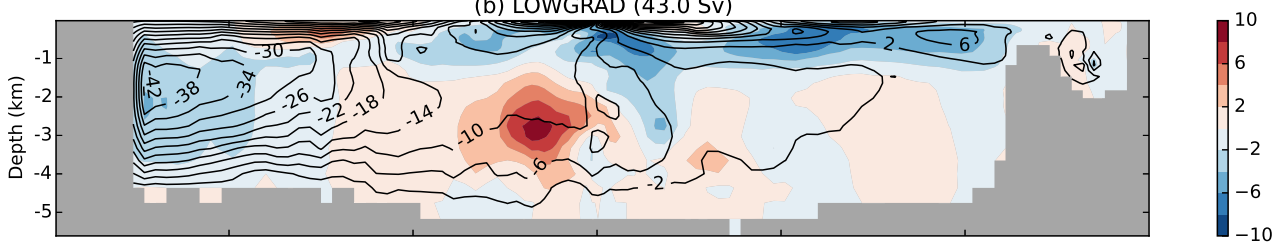

(c) LOWGRADWIND (41.7 Sv)

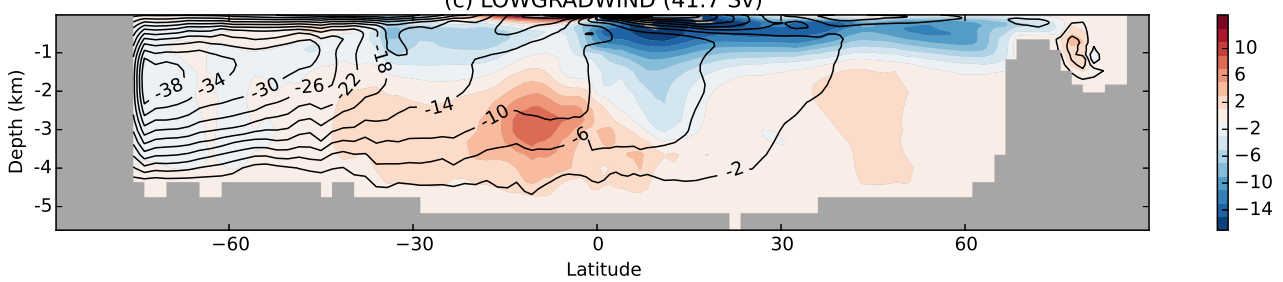

Figure 3. Global meridional overturning circulation streamfunction for (a) the control case CNTRL, with colour plot representing the streamfunction (b) the low temperature gradient case, LOWGRAD, with colour plot representing LOWGRAD-CNTRL streamfunction difference and (c) the low temperature and weak wind case, LOWGRADWIND, with colour plot representing LOWGRADWIND-CNTRL streamfunction difference. Values are given in $\mathrm{Sv}\left(1 \mathrm{~Sv}=10^{6} \mathrm{~m}^{3} \mathrm{~s}^{-1}\right)$. The strength of the Southern Hemisphere overturning cell is given in parentheses in the captions.

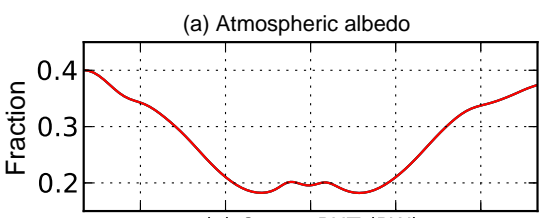

(c) Ocean PHT (PW)

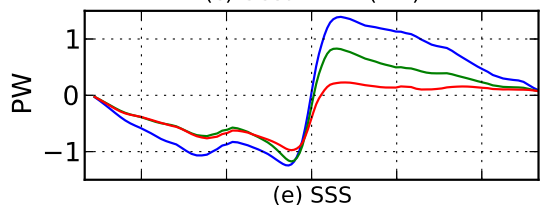

(e) SSS

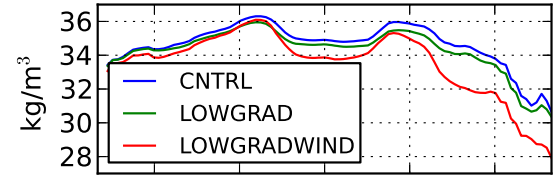

(g) Density at $500 \mathrm{~m}$ depth $\left(\mathrm{kg} / \mathrm{m}^{3}\right)$

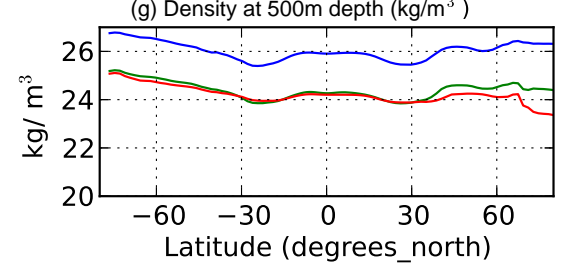

(b) Outgoing LWR $\left(\mathrm{W} / \mathrm{m}^{2}\right)$

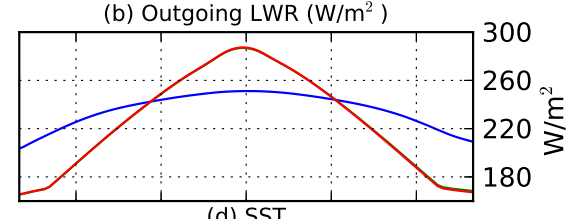

(d) SST

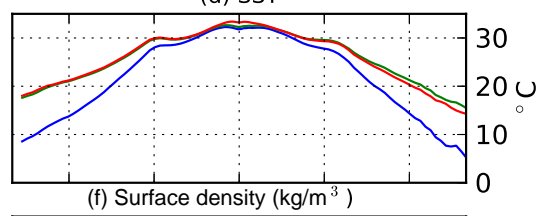

(f) Surface density $\left(\mathrm{kg} / \mathrm{m}^{3}\right)$

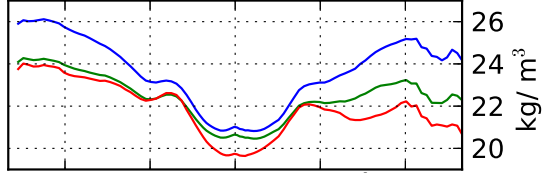

(h) Density at $1000 \mathrm{~m}$ depth $\left(\mathrm{kg} / \mathrm{m}^{3}\right)$

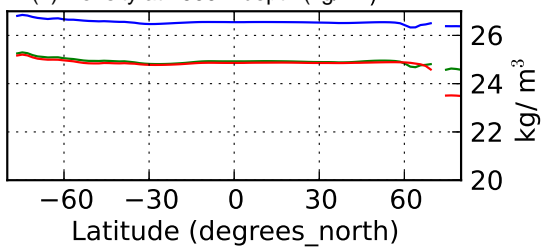

Figure 4. Global zonal mean of (a) atmospheric albedo (fraction) (b) outgoing longwave radiation $\left(\mathrm{W} \mathrm{m}^{-2}\right.$ ), (c) oceanic poleward heat transport (petawatts), (d) sea surface temperature $\left(\mathrm{SST},{ }^{\circ} \mathrm{C}\right),(\mathbf{e})$ sea surface salinity $\left(\mathrm{SSS}, \mathrm{kg} \mathrm{m}^{-3}\right)$ and (f) ocean potential density $\left(\mathrm{kg} \mathrm{m}^{-3}\right)$ for the control case CNTRL (blue), the low temperature gradient case LOWGRAD (green), and the low temperature and weak wind case LOWGRADWIND (red). Bottom row as (f) at depths (g) $500 \mathrm{~m}$ and (h) $1000 \mathrm{~m}$. 

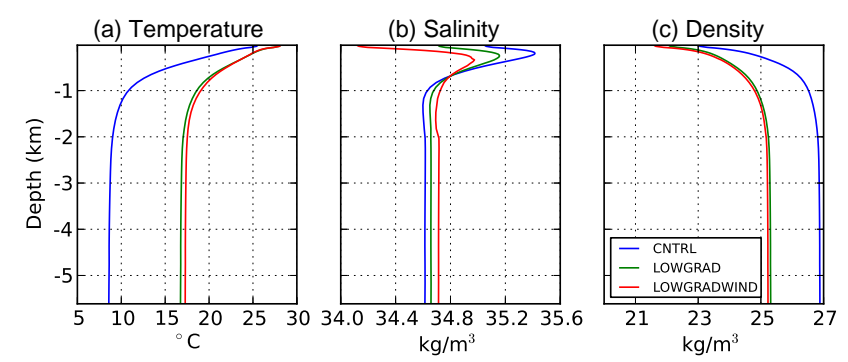

Figure 5. Vertical profiles of global horizontal mean in ocean of (a) temperature $\left({ }^{\circ} \mathrm{C}\right)$, (b) salinity $\left(\mathrm{kg} \mathrm{m}^{-3}\right)$ and (c) ocean potential density $\left(\mathrm{kg} \mathrm{m}^{-3}\right)$ for the control case CNTRL (blue), the low temperature gradient case LOWGRAD (green), and the low temperature and weak wind case LOWGRADWIND (red).

Figure 5a shows that the vertical ocean potential temperature gradient is significantly smaller in the model under the enhanced greenhouse effect at high latitudes in LOWGRAD compared to the control case CNTRL. This illustrates how the meridional surface temperature gradient maps into the deep ocean. Deep ocean temperatures are around $9^{\circ} \mathrm{C}$ in $\mathrm{CN}$ TRL, whereas they are around $17^{\circ} \mathrm{C}$ in LOWGRAD, corresponding to the very mild winter temperatures at the simulated deep sinking regions at the Pacific sector of the Antarctic coast. The warm deep ocean temperatures in the LOWGRAD simulation are in good agreement with the early Turonian deep water temperature estimates of $19^{\circ} \mathrm{C}$ of Huber et al. (2001).

Reducing the wind stress, as in LOWGRADWIND, does not lead to a significant change in temperature profile. The vertical salinity gradients are somewhat reduced in LOWGRAD compared to CNTRL (Fig. 5b), and more strongly reduced in LOWGRADWIND. This indicates that the overall fresher SSS values in LOWGRADWIND (Fig. 4e) arise from a general relocation of salt from the shallow ocean to the deep ocean there. The vertical density gradient is also reduced in LOWGRAD with respect to CNTRL (Fig. 5c), with a vertical density difference between the top and bottom layer of $4.4 \mathrm{~kg} \mathrm{~m}^{-3}$ in CNTRL, and $3.7 \mathrm{~kg} \mathrm{~m}^{-3}$ in LOWGRAD. This indicates an overall less stratified ocean when meridional temperature gradients are reduced.

The overturning circulation pattern can also be recognised in the global vertical profile of the meridional velocity south of $30^{\circ} \mathrm{N}$, shown in Fig. $6 \mathrm{a}$. The velocity profile is very similar for CNTRL and LOWGRAD, yet differs near the surface in LOWGRADWIND where the average velocity is somewhat more southward. Examination of the overturning streamfunction anomaly in Fig. 3c (colour background) indicates that this is related to the reduction in the shallow northern cell. Meridional velocities cancel around $2000 \mathrm{~m}$ depth in all three simulations. This depth lies in between an upper southward moving branch and a lower northward moving branch, in agreement with the meridional overturning streamfunction (Fig. 3). This depth range coincides with a
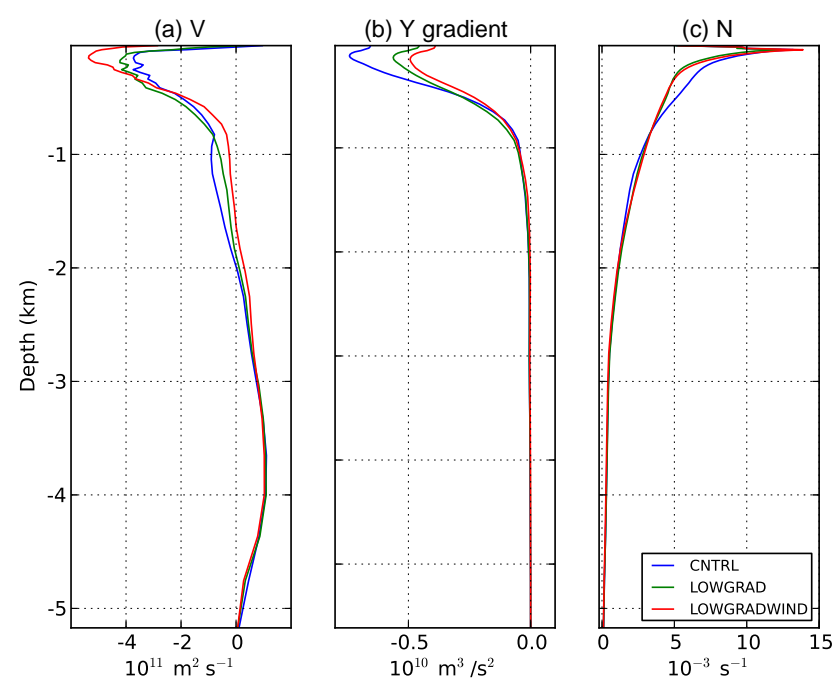

Figure 6. Vertical depth profiles of horizontal mean (south of $30^{\circ} \mathrm{N}$ ) of (a) meridional velocity $u\left(10^{-4} \mathrm{~m} \mathrm{~s}^{-1}\right)$, (b) latitudinal $(y)$ derivative of density $\frac{\partial \rho}{\partial y}\left(\mathrm{~kg} \mathrm{~m}^{-4}\right)$ and (c) the buoyancy frequency $N=\sqrt{-\frac{g}{\rho_{0}} \frac{\partial \rho}{\partial z}}$ (in units $\mathrm{s}^{-1}$ ) for the control case CNTRL (blue), the low temperature gradient case LOWGRAD (green), and the low temperature and weak wind case LOWGRADWIND (red). Bottom labels indicate units.

local minimum in kinetic energy. Kinetic energy does not assume values close to zero at this minimum, indicating that the cancellation of meridional velocities in the horizontal average in part masks a horizontal gyre circulation.

\section{Comparison with data inferred from proxies}

Subpolar Atlantic summer temperatures around $60^{\circ} \mathrm{S}$ are between 20 and $24^{\circ} \mathrm{C}$ in LOWGRAD (Fig. 1a). This is in agreement with similar estimates by Bice et al. (2003) based on oxygen isotope data for the Falkland Plateau, around $60^{\circ} \mathrm{S}$ palaeolatitude, for the mid-Turonian, and lower than the $30-32{ }^{\circ} \mathrm{C}$ they reported for a warm excursion during the late Turonian. The good deep ocean temperature agreement with proxies (see below) indicates that our modification of the atmospheric radiative balance yields a good simulation of polar surface temperatures at the southern source regions. Equatorial temperatures are around $32-33^{\circ} \mathrm{C}$ for LOWGRAD and LOWGRADWIND in the zonal mean (Fig. 4d). A localised warm pool in the Tethys, where temperatures reach $36^{\circ} \mathrm{C}$ (Fig. 1b), constitutes a significant departure from the zonal mean. This is in agreement with the high tropical temperatures of $33-34^{\circ} \mathrm{C}$ found by Norris et al. (2002), Schouten et al. (2003) and Wilson et al. (2002).

We intend to illustrate a wider timeframe of greenhouse climates, and will therefore briefly discuss the Eocene. Southwest Pacific SSTs increased to $\sim 32^{\circ} \mathrm{C}$ during the early Eocene ( $\sim 53 \mathrm{Ma}$ ago $)$, and decreased to $\sim 21^{\circ} \mathrm{C}$ by the late Eocene ( $\sim 36 \mathrm{Ma}$ ago Bijl et al., 2009). This later 
cooler Eocene temperature is close to our Cretaceous simulation LOWGRAD in the Southwest Pacific. Tropical conditions (around 25 to $30^{\circ} \mathrm{C} \mathrm{SSTs)} \mathrm{may} \mathrm{have} \mathrm{prevailed} \mathrm{at} \mathrm{the}$ Canterbury Basin $\left(55^{\circ} \mathrm{S}\right.$ palaeolatitude) from the late-early to early-middle Eocene (50.7-46.5 Ma) according to Hollis et al. (2009), although uncertainties related to TEX 86 suggest peak temperatures at site 1172 may have been $28^{\circ} \mathrm{C}$ (Hollis et al., 2012). Douglas et al. (2014) present palaeotemperature records that indicate that the Seymour Island middle and late Eocene SSTs ranged between 10 to $17^{\circ} \mathrm{C}$. This is significantly cooler than the temperatures found elsewhere for similar sub-polar latitudes. These findings point to a significantly reduced meridional temperature gradient during the Cretaceous and Eocene.

We find southern sinking in our simulations. Although it is difficult to infer meridional overturning circulation polarity for the Turonian, Cramer et al. (2009) argue that more homogeneous deep ocean conditions before the late Eocene arose from deep sinking in both hemispheres, and that a period of enhanced heterogeneity during the late Cretaceous may have arisen from changes in the ability of winds to make water in the deep ocean circulate via a Tethyan circum-equatorial current that might have functioned in analogous fashion to the Antarctic Circumpolar Current (Hotinski and Toggweiler, 2003). For the Eocene, Corfield and Norris (1996), Thomas et al. (2003), Thomas (2004), Via and Thomas (2006) and Coxall and Pearson (2007) find proxy evidence for deep ocean ventilation from the south. A further discussion of the warm polar conditions during the greenhouse climates, including terrestrial proxies, can be found in Sijp et al. (2014).

\section{Discussion and conclusion}

Schewe and Levermann (2010) showed that the deep ocean meridional density gradients at the western boundaries determine the meridional flow in the deep western boundary current responsible for the main meridional volume transport of each ocean basin. The depth of the density gradient is taken inside the depth range of the deep branch of the meridional overturning cell. Sijp et al. (2011a) build on this finding, showing that the volume transport in the Atlantic meridional overturning cell that crosses the Equator depends on the deep buoyancy distribution, and provide a theoretical underpinning based on a level of no motion between the upper and lower overturning branches. Namely, meridional flow in the deep western boundary current of the North Atlantic Deep Water outflow depends only on meridional density gradients below the intermediate depth interface between the North Atlantic Deep Water and the Antarctic Intermediate Water masses, and not above, due to vanishing horizontal pressure gradients near the interface.

The analogue to the quiescent zone inside the overturning cell in our Cretaceous model is the interface between the upper and lower branches of the large southern sinking cell, at around $2000 \mathrm{~m}$ depth. Although meridional density gradients (Fig. 6b) differ between CNTRL and LOWGRAD at the surface (see also Fig. 4f), they are remarkably similar below $500 \mathrm{~m}$ depth. According to Schewe and Levermann (2010) and Sijp et al. (2011a), it is the deep density structure that sets the strength of the deep overturning branch, and therefore the southern sinking cell. As a result, the overturning circulation (Fig. 3) and the oceanic meridional velocity (Fig. 6a) remain remarkably similar when the meridional SST gradient is strongly reduced due to an extratropical enhancement of the greenhouse effect. In contrast, the upper branch of the MOC is not primarily driven by the density gradients, as surface steric height gradients become important there. Therefore, we do not link changes in the upper branch of the MOC to changes in density gradients. Of course in the hypothetical case where the SST gradient is entirely absent and salinity effects are weak, overturning is expected to be absent. Nonetheless, the SST gradients appropriate for the past greenhouse climates are not sufficiently low to yield reduced overturning.

In today's ocean, the sub-thermocline ocean is filled with water sourced from three climatically distinct regions: namely, the North Atlantic Deep Water, the Antarctic Intermediate Water and the Antarctic Bottom Water formation regions. This yields three corresponding vertically stacked water masses that can be found across the globe, providing the deep ocean density differences that drive flow there. Indeed, Sijp et al. (2011a) showed that it is the density difference between Antarctic Intermediate Water and the underlying North Atlantic Deep Water in the tropical Atlantic that drives the conveyor belt circulation. In sharp contrast, the deep ocean is filled from only one source in the Southern Ocean in our Cretaceous experiments. This is similar to the simulation of Sijp and England (2004) where the Drake Passage is closed in the present-day geography, and a large Southern Hemisphere cell fills the deep ocean, leading to a sharp vertical density gradient in the thermocline, and a more homogeneous deep ocean. In our experiments here, we also find that the single confined surface origin of deep water leads to a relatively homogeneous body of water masses below the thermocline. This is apparent from the vertical density profile (Fig. 5c), and the vertical profile of the buoyancy frequency $N=\sqrt{-\frac{g}{\rho_{0}} \frac{\partial \rho}{\partial z}}$ shown in Fig. 6c. Only diapycnal diffusivity leads to small density gradients within this water mass, driving the ocean currents. As a result, the deep ocean density gradients remain remarkably similar across the experiments, as shown by the vertical profiles of the meridional density gradient (Fig. 6b) and the buoyancy frequency (Fig. 6c), and zonal means of density (Fig. $4 \mathrm{~g}$ and h). This is because the deep water source region warms, and this leads to a uniform warming of the deep ocean as there are no other source regions of note, and density gradients remain relatively unchanged as they depend on isopycnal diffusivity. 
Rose and Ferreira (2013) note the contradiction of weak meridional temperature gradients demanding increased PHT, while simultaneously implying weak PHT. They show this to be a mere paradox, as extratropical radiative balance responses to heat transport from low latitudes may warm the high latitudes without cooling the Tropics. In our experiments, we do not examine the mechanisms behind the altered radiative balance, and do not distinguish between the mechanisms of Rose and Ferreira (2013) or Abbot and Tziperman (2008), or the warming-enhancing cloud mechanism at play in the simulations of Yang et al. (2013). Instead, we have prescribed an altered radiative balance, of a similar nature to that implied via these mechanisms, by enhancing the extratropical greenhouse effect, and reducing it in the Tropics. As a result, heat transport is reduced while the meridional temperature gradient is also smaller, illustrating the paradox of Rose and Ferreira (2013).

In summary, a substantial reduction of the pole-to-Equator temperature difference leaves the meridional overturning circulation relatively unaffected in our Cretaceous model. Reducing the wind strength also has remarkably little effect on the overturning. This is because overturning strength depends on deep ocean density gradients, which remain relatively unaffected by the applied radiative changes, despite an overall decrease in ocean density. Ocean poleward heat transport is reduced, as now the circulation operates across a reduced temperature gradient. These results indicate that models of the greenhouse climate during the Cretaceous and early Paleogene may yield a reasonable overturning circulation, despite failing to fully reproduce the extremely reduced temperature gradients of those time periods.

Acknowledgements. We thank the University of Victoria staff for support in usage of their coupled climate model. We thank Sascha Floegel for the pleasant collaboration leading to the Cretaceous model. This research was undertaken with the assistance of resources provided at the Katana computation cluster at the UNSW Faculty of Science. This project was supported by the Australian Research Council, including support from an ARC Laureate Fellowship (FL100 100214) and the ARC Centre of Excellence for Climate System Science (CE110 001 028).

Edited by: A. Haywood

\section{References}

Abbot, D. and Tziperman, E.: A high latitude convective cloud feedback and equable climates, J. Roy. Meteorol. Soc., 134, 165-185, doi:10.1002/qj.211, 2008.

Abbot, D., Huber, M., Bousquet, G., and Walker, C. C.: High$\mathrm{CO}_{2}$ cloud radiative forcing feedback over both land and ocean in a global climate model, Geophys. Res. Lett., 36, L05702, doi:10.1029/2008GL036703, 2009.
Albert, J. S.: A model for the thermodynamic growth of sea ice in numerical investigations of climate, J. Phys. Oceanogr., 6, 379389, 1976.

Alexeev, V. A.: Sensitivity to $\mathrm{CO}_{2}$ doubling of an atmospheric GCM coupled to an oceanic mixed layer: a linear analysis, Clim. Dynam., 20, 775-787, 2003.

Alexeev, V. A.: Polar amplification of surface warming on an aquaplanet in ghost forcing experiments without sea ice feedbacks, Clim. Dynam., 24, 655-666, doi:10.1007/s00382-005-0018-3, 2005.

Barron, E. J.: A warm, equable Cretaceous: the nature of the problem, Earth-Sci. Rev., 19, 305-338, 1983.

Barron, E. J.: Eocene equator-to-pole surface ocean temperatures: a significant climate problem?, Paleoceanography, 2, 729-739, 1987.

Bice, K. L., Huber, B. T., and Norris, R. D.: Extreme polar warmth during the Cretaceous greenhouse?: Paradox of the late Turonian $\delta^{18} \mathrm{O}$ record at DSDP site 511, Paleoceanography, 18, 1031, doi:10.1029/2002PA000848, 2003.

Bijl, P. K., Schouten, S. S., and Sluijs, A.: Early palaeogene temperature evolution of the Southwest Pacific Ocean, Nature, 461, 776-779, 2009.

Blanke, B. and Delecluse, P.: Variability of the tropical atlantic ocean simulated by a general circulation model with two different mixed-layer physics, J. Phys. Oceanogr., 23, 1363-1388, 1993.

Brass, G. W., Southam, J. R., and Peterson, W. H.: Warm saline bottom water in the ancient ocean, Nature, 296, 620-623, 1982.

Caballero, R. and Langen, P.: The dynamic range of poleward energy transport in an atmospheric general circulation model, Geophys. Res. Lett., 32, L02705, doi:10.1029/2004GL021581, 2005.

Clarke, L. J. and Jenkyns, H. C.: New oxygen isotope evidence for long-term Cretaceous climatic change in the Southern Hemisphere, Geology, 27, 699-702, 1999.

Corfield, R. M. and Norris, R. D.: Deep water circulation in the Paleocene ocean, Geol. Soc. Lond. Spec. Publ., 101, 443-456, 1996.

Coxall, H. K. and Pearson, P. N.: The Eocene-Oligocene transition, in: Deep Time Perspectives on Climate Change: Marrying the signal from computer models and biological proxies, edited by: Williams, M., Haywood, A. M., Gregory, F. J., and Schmidt, D. N., The Micropaleontological Society Special Publication, The Geological Society, London, 351-389, 2007.

Cramer, B. S., Toggweiler, J. R., Wright, J. D., Katz, M. E., and Miller, K. G.: Ocean overturning since the late cretaceous: Inferences from a new benthic foraminiferal isotope compilation, $\mathrm{Pa}$ leoceanography, 24, PA4216, doi:10.1029/2008PA001683, 2009.

Douglas, P. M. J., Affek, H. P., and Ivany, L. C.: Pronounced zonal heterogeneity in Eocene southern high-latitude sea surface temperatures, P. Natl. Acad. Sci., 111, 6582-6587, 2014.

Enderton, D. and Marshall, J.: Controls on the total dynamical heat transport of the atmosphere and oceans, J. Atmos. Sci., 66, 15931611, 2009.

Floegel, S., Hay, W. W., DeConto, R. M., and Balukhovsky, A. N.: Formation of sedimentary bedding couplets in the western interior seaway of North America-implications from climate system modeling, Palaeogeogr. Palaeocl., 218, 125-143, doi:10.1016/j.palaeo.2004.12.011, 2005. 
Gaspar, P., Gregoris, Y., and Lefevre, J. M.: A simple eddy kinetic energy model for simulations of the oceanic vertical mixing: tests at station papa and long-term upper ocean study site, J. Geophys. Res., 95, 16179-16193, 1990.

Gnanadesikan, A.: A simple predictive model for the structure of the oceanic pycnocline, Science, 283, 2077-2079, 1999.

Greenwood, D. R. and Wing, S. L.: Eocene continental climates and latitudinal temperature gradients, Geology, 23, 1044-1048, 1995.

Herweijer, C., Seager, R., Winton, M., and Clement, A.: Why ocean heat transport warms the global mean climate, Tellus A, 57, 662$675,2005$.

Holland, M. M. and Bitz, C. M.: Polar amplification of climate change in coupled models, Clim. Dynam., 21, 221-232, 2003.

Hollis, C. J., Handley, L., Crouch, E. M., Morgans, H. E. G., Baker, J. A., Creech, J., Collins, K. S., Gibbs, S. J., Huber, M., Schouten, S., Zachos, J. C., and Pancost, R. D.: Tropical sea temperatures in the high-latitude south pacific during the eocene, Geology, 37, 99-102, 2009.

Hollis, C. J., Taylor, K. W. R., Handley, L., Pancost, R. D., Huber, M., Creech, J. B., Hines, B. R., Crouch, E. M., Morgans, H. E. G., Crampton, J. S., Gibbs, S., Pearson, P. N., and Zachos, J. C.: Early Paleogene temperature history of the Southwest Pacific Ocean: Reconciling proxies and models, Earth Planet. Sc. Lett., 349, 53-66, 2012.

Hotinski, R. M. and Toggweiler, J. R.: Impact of a Tethyan circumglobal passage on ocean heat transport and "equable" climates, Paleoceanography, 18, 1007, doi:10.1029/2001PA000730, 2003.

Huber, B. T., Norris, R. D., and McLeod, K. G.: Deep-sea paleotemperature record of extreme warmth during the cretaceous, Geology, 30, 123-126, 2001.

Huber, M. and Caballero, R.: Eocene El Nino: evidence for robust tropical dynamics in the "hothouse", Science, 299, 877-881, 2003.

Huber, M. and Caballero, R.: The early Eocene equable climate problem revisited, Clim. Past, 7, 603-633, doi:10.5194/cp-7603-2011, 2011.

Kuhlbrodt, T., Griesel, A., Montoya, M., Levermann, A., Hofmann, M., and Rahmstorf, S.: On the driving processes of the Atlantic meridional overturning circulation, Rev. Geophys., 45, RG2001, doi:10.1029/2004RG000166, 2007.

Langen, P. and Alexeev, V.: Polar amplification as a preferred response in an idealized aquaplanet GCM, Clim. Dynam., 29, 305317, 2007

Lear, C. H., Elderfield, H., and Wilson, P. A.: Cenozoic deep-sea temperatures and global ice volumes from $\mathrm{Mg} / \mathrm{Ca}$ in benthic foraminiferal calcite, Science, 287, 269-272, 2000.

Littler, K., Robinson, S. A., Bown, P. R., Nederbragt, A. J., and Pancost, R. D.: High sea-surface temperatures during the early cretaceous epoch, Nat. Geosci., 4, 169-172, 2011.

Lunt, D. J., Dunkley Jones, T., Heinemann, M., Huber, M., LeGrande, A., Winguth, A., Loptson, C., Marotzke, J., Roberts, C. D., Tindall, J., Valdes, P., and Winguth, C.: A modeldata comparison for a multi-model ensemble of early Eocene atmosphere-ocean simulations: EoMIP, Clim. Past, 8, 17171736, doi:10.5194/cp-8-1717-2012, 2012.

Miller, K. G., Fairbanks, R. G., and Mountain, G. S.: Tertiary oxygen isotope synthesis, sea level history, and continental margin erosion, paleoceanography, Paleoceanography, 2, 1-19, doi:10.1029/PA002i001p00001, 1987.

Norris, R. D., Bice, K. L., Magno, E. A., and Wilson, P. A.: Jiggling the tropical thermostat in the Cretaceous hothouse, Geology, 30, 299-302, 2002.

Pacanowski, R.: MOM2 Documentation User's Guide and Reference Manual: GFDL Ocean Group Technical Report 3, 3rd Edn., NOAA, GFDL, Princeton, 232 pp., 1995.

Rahmstorf, S.: On the freshwater forcing and transport of the Atlantic thermohaline circultion, Clim. Dynam., 12, 799-811, 1996.

Roberts, C. D., LeGrande, A. N., and Tripati, A. K.: Climate sensitivity to Arctic seaway restriction during the early Paleogene, Earth Planet. Sc. Lett., 286, 576-585, 2009.

Robinson, A. R.: The general thermal circulation in equatorial regions, Deep-Sea Res., 6, 311-317, 1960.

Robinson, A. R. and Stommel, H.: The oceanic thermocline and the associated thermohaline circulation, Tellus, 11, 295-308, 1959.

Rose, B. E. J. and Ferreira, D.: Ocean heat transport and water vapor greenhouse in a warm equable climate: a new look at the low gradient paradox, J. Climate, 26, 2117-2136, 2013.

Schewe, J. and Levermann, A.: The role of meridional density differences for a wind-driven overturning circulation, Clim. Dynam., 34, 547-556, 2010.

Schouten, S., Hopmans, E. C., Forster, A., van Breugel, Y., Kuypers, M. M., and Damste, J. S. S.: Extremely high sea-surface temperatures at low latitudes during the middle Cretaceous as revealed by archaeal membrane lipids, Geology, 31, 1069-1072, 2003.

Sijp, W. P. and England, M. H.: Effect of the Drake Passage throughflow on global climate, J. Phys. Oceanogr., 34, 1254-1266, 2004.

Sijp, W. P., England, M. H., and Gregory, J. M.: Precise calculations of the existence of multiple AMOC equilibria in coupled climate models part I: equilibrium states, J. Climate, 25, 282-298, 2011a.

Sijp, W. P., England, M. H., and Huber, M.: Effect of deepening of the Tasman Gateway on the global ocean, Paleoceanography, 26, PA4207, doi:10.1029/2011PA002143, 2011b.

Sijp, W. P., von der Heydt, A. S., Dijkstra, H. A., Flögel, S., Douglas, P., and Bijl, P. K.: The role of ocean gateways on cooling climate on long time scales, Global Planet. Change, 119, 1-22, 2014.

Thomas, D.: Evidence for deep-water production in the north pacific ocean during the early cenozoic warm interval, Nature, 430, 6568, 2004.

Thomas, D., Bralower, T. J., and Jones, C. E.: Neodymium isotopic reconstruction of the late paleocene- early eocene thermohaline circulation, Earth Planet. Sc. Lett., 209, 309-322, 2003.

Toggweiler, J. R. and Samuels, B. L.: Effect of Drake Passage on the global thermohaline circulation, Deep-Sea Res. Pt. I, 42, 477500, 1995.

Valdes, P.: Built for stability, Nat. Geosci., 4, 414-416, 2011.

Via, R. and Thomas, D.: Evolution of atlantic thermohaline: Early oligocene circulation onset of deep-water production in the north atlantic, Geology, 34, 441-444, 2006.

Weaver, A. J., M. Eby, Wiebe, E. C., Bitz, C. M., Duffy, P. B., Ewen, T. L., Fanning, A. F., Holland, M. M., MacFadyen, A., Matthews, H. D., Meissner, K. J., Saenko, O., Schmittner, A., Wang, H., and Yoshimori, M.: The UVic Earth System Climate Model: model 
description, climatology, and applications to past, present and future climates, Atmos. Ocean, 39, 1067-1109, 2001.

Wilson, P. A., Norris, R. D., and Cooper, M. J.: Testing the Cretaceous greenhouse hypothesis using glassy foraminiferal calcite from the core of the Turonian tropics on Demerara Rise, Geology, 30, 607-610, 2002.

Wolfe, J.: Paleoclimate estimates from Tertiary leaf assemblages, Annu. Rev. Earth Pl. Sc., 23, 119-142, 1995.
Yang, S., Galbraith, E., and Palter, J.: Coupled climate impacts of the Drake Passage and the Panama Seaway, Clim. Dynam., 43, 37-52, 2013.

Zachos, J. C., Pagani, M., Sloan, L., Thomas, E., and Billups, K.: Trends, rythms, and aberrations in global climate $65 \mathrm{Ma}$ to present, Science, 292, 686-693, 2001a. 